\title{
ECS-produced disruption of a go, no-go discrimination in rats*
}

\author{
JOSEPH B. KEYES \\ Louisiana State University, Baton Rouge, La. 70803
}

Sixteen male albino rats were trained on a GO-light on (off), NO-GO-light off (on) leverpress discrimination task using a discrete trial procedure. Reinforcement was given on a variable ratio schedule (VR 2). All Ss were trained to a criterion of $90 \%$. Following training, half the Ss were given ECS and the other Ss received no treatment. The Ss given ECS showed a deficit in performance when tested $24 \mathrm{~h}$ later. The results were discussed in terms of a disruption of a response inhibition mechanism.

The most widely accepted explanation of the effect of electroconvulsive shock (ECS) has been the memory consolidation hypothesis (McGaugh, 1966). According to this theory, after sensory input, memory is in the form of a trace which undergoes neural consolidation and thereby becomes fixed or permanent. During this fixation period, the memory trace is susceptible to disruption, and if ECS is administered, a permanent memory loss will result.

Recently, however, Young \& Day (1971) have suggested another explanation. According to Young and Day, the effect of ECS may be a perseveration of responding in extinction rather than retrograde amnesia (RA). They further suggest that this effect would be more noticeable for continuous reinforcement-trained Ss, which cease responding in extinction sooner than Ss trained on a partial reinforcement schedule (PR). The result would be a reduction in the difference between the continuous reinforcement (CRF) and PR groups, and therefore a loss of the partial reinforcement effect (PRE).

In order to test these predictions, Keyes \& Young (1973) trained rats to leverpress using a discrete trial procedure. They found that after 1,000 leverpresses, CRF-trained Ss given ECS made significantly more responses in extinction than CRF-trained Ss given no treatment. However, Ss trained on a fixed ratio schedule (FR-3) and given ECS did not respond significantly more than FR-trained Ss given no treatment. In addition, there was a loss of the PRE in extinction.

These results support the predictions of the Young \& Day (1971) perseveration hypothesis. A perseveration effect has also been obtained in extinction with a free operant leverpress procedure at 100 leverpresses but not at 300,500 , or 1,000 leverpresses (Keyes, 1973; Galluscio, 1971) and with a runway response at low levels of motivation (Keyes \& Dempsey, 1973). In general, these studies suggest that a perseveration effect produces an increase in resistance to extinction when the

*This research was supported in part by a grant from the University Council on Research, LSU, to A. G. Young, who sponsors the paper and takes full editorial responsibility for it. level of resistance to extinction is low prior to ECS treatment.

One possible explanation of these findings is that ECS might interfere with the development of inhibition underlying normal extinction, and the present experiment was designed to investigate the effect of ECS on the ability of rats to withhold (inhibit) responding in a GO, NO-GO discrimination paradigm.

\section{METHOD \\ Subjects}

The Ss were 16 naive male albino rats, $175-200 \mathrm{~g}$ in weight at the start of the experiment.

\section{Apparatus}

The apparatus consisted of two identical Scientific Prototype operant chambers, each enclosed in a sound-insulated, ventilated cubicle. Each operant chamber had a grid floor, and fitted on the end wall was a retractable lever and a liquid dipper that dispensed $.01 \mathrm{ml}$ of a $40 \%$ sucrose solution used as reinforcement. All E-controlled events were operated by an electronic programming device.

\section{Procedure}

The Ss were selected randomly from the LSU colony, placed in individual cages, and kept on a food deprivation schedule consisting of $10 \mathrm{~g}$ Purina Chow every $24 \mathrm{~h}$. Water was available in the cages at all times, and Ss were fed approximately $10 \mathrm{~min}$ after each experimental session. On Days 1-4, Ss were adapted to the deprivation schedule. On Days 5-8, Ss were handled in pairs for 5 min daily, and on the 9th day, Ss began magazine training on a VI $30-\mathrm{sec}$ schedule. Experimental periods consisted of 20 presentations of the dipper and were continued for 4 days. On Day 13, all Ss were trained to leverpress. On Day 14, Ss were allowed to make 100 reinforced responses with the GO stimulus condition in effect, that is, houselight on for half the Ss and houselight off for the other Ss. On Day 15, acquisition training was begun. The following GO, NO-GO stimulus conditions were used: for half the Ss the GO stimulus was the houselight on and the NO-GO stimulus was the houselight off, for the other Ss the GO stimulus was the houselight off and the NO-GO stimulus was the houselight on. Leverpressing was reinforced on a variable ratio (VR 2) schedule when the GO stimulus was in effect. The GO, NO-GO stimulus conditions were controlled by a variable interval schedule (VI $1 \mathrm{~min}$ ). Daily experimental sessions were $30 \mathrm{~min}$ in duration. The Ss were run daily, until their response ratio percentage (number of responses in GO condition/total number of responses), 100 for one day, reached $90 \%$. A discrete trial procedure was used and the lever, which required $4 \mathrm{sec}$ to retract and extend fully, was inoperative during retraction.

Following the completion of acquisition training, the Ss were subdivided randomly, resulting in the following two groups $(\mathrm{N}=8)$ : Group EXP: Immediately following the completion of acquisition, $\mathrm{Ss}$ in this group were fitted with microalligator earclips and administered a 50-mA, 500-msec ECS. Group NT: For Ss in this group, treatment was identical to that of the group above, except that no ECS was delivered.

Twenty-four hours after treatment, all Ss were returned to the apparatus and tested on the GO, NO-GO task. The conditions during testing were identical to those during acquisition.

\section{RESULTS}

There was no significant difference in the number of 
Table 1

Mean Response Ratio Percentages

\begin{tabular}{lcc}
\hline & Criterion & Test \\
Group & Day & Day \\
\hline EXP & 93.53 & 86.02 \\
NT & 92.14 & 95.50 \\
\hline
\end{tabular}

days to criterion between the EXP and NT groups, or for the response ratio percentages on criterion day (Mann-Whitney U tests). Therefore, the EXP and NT group response ratio percentages on the test day were directly compared. The EXP vs NT group comparison was significant beyond the .01 level (Mann-Whitney U). Table 1 shows the mean response ratio percentages on criterion day and on test day for the EXP and NT groups.

An analysis of the number of responses made on criterion day vs test day for the GO and NO-GO stimulus conditions was conducted. The results showed that the number of responses on test day during the NO-GO condition was significantly more than it was on criterion day for the EXP group ( $<<.01$, Wilcoxon). For the NT group fewer responses were made on test day than on criterion day during the NO-GO condition $(\mathrm{p}<.05$, Wilcoxon). The NT group made significantly more responses on test day than on criterion day during the GO condition $(\mathrm{p}<.01$, Wilcoxon). For the EXP group, during the GO condition, more responses were made on test day than on criterion day, but the difference was not significant at the .05 level (Wilcoxon).

\section{DISCUSSION}

A critical finding of this study is that ECS seems to impair performance on a well-trained GO, NO-GO discrimination, a task which requires an animal to inhibit responding when the NO-GO stimulus condition is in effect.

A second major finding of this study is that Ss given ECS made more responses, during the NO-GO condition, on test day than on criterion day, however, Ss given no treatment made fewer responses on test day than on criterion day.

These findings suggest that ECS may disrupt the organism's "response-inhibition" mechanism. During training, S learns to inhibit responding when the NO-GO stimulus condition is in effect, and ECS, then, may produce an inability to suppress formerly inhibited responding.

The present findings are consistent with those reported by Keyes \& Young (1973), Keyes (1973), and Keyes \& Dempsey (1973). These studies found perseveration of responding in extinction following the administration of ECS. If extinction develops through the buildup of response inhibition and ECS disrupts the animal's "response-inhibition" mechanism, then the result of ECS administration would be an increase in resistance to extinction.

A possible alternative explanation of the present study might be that ECS interrupts consolidation and thereby produces RA for the GO, NO-GO discrimination task. However, this explanation seems unlikely since no studies have reported RA when the training period has extended more than 1 day (McGaugh, 1966). In the present study, no $S$ learned the discrimination in less than 3 days. Furthermore, RA has been demonstrated with descrimination learning only when Ss have been trained to a criterion of $75 \%$ or less (Thompson, 1958), while in the present study a criterion of $90 \%$ was used. The present study therefore suggests that the effect of ECS is not RA but, rather, may be the disruption of a "response-inhibition" mechanism.

\section{REFERENCES}

Galluscio, E. H. Retrograde amnesia induced by electroconvulsive shock and carbon dioxide anesthesia in rats: An attempt to stimulate recovery. Journal of Comparative \& Physiological Psychology, 1971, 75, 136-140.

Keyes, J. B. ECS perseveration effect following varying amounts of training. Physiological Psychology, 1973, 1, 2-4.

Keyes, J. B., \& Dempsey, G. L. The effect of motivational states on ECS-induced perseveration. Physiological Psychology, 1973 , in press.

Keyes, J. B., \& Young, A. G. ECS effects: The PRE. Bulletin of the Psychonomic Society, 1973, 1, 39-40.

McGaugh, J. L. Time-dependent processes in memory storage. Science, 1966, 153, 1351-1358.

Thompson, R. The effect of degree of learning and problem difficulty on perseveration. Journal of Experimental Psychology, 1958, 55, 496-500.

Young, A. G., \& Day, H. D. Effect of ECS on one-trial learning on the partial reinforcement effect. Psychonomic Science, $1971,24,99-100$

(Received for publication March 30, 1973.) 